\title{
Rudolf Schieffer, Die Zeit des karolingischen Großreichs (714-887)
}

Stuttgart : Klett-Cotta (Gebhardt, Handbuch der deutschen Geschichte, 10e édition, vol. 2), 2005, 187 p., $30 €$

\section{Philippe Depreux}

\section{OpenEdition}

\section{Journals}

Édition électronique

URL : http://journals.openedition.org/ifha/7703

DOI : 10.4000/ifha.7703

ISSN : 2198-8943

\section{Éditeur}

IFRA - Institut franco-allemand (sciences historiques et sociales)

\section{Référence électronique}

Philippe Depreux, «Rudolf Schieffer, Die Zeit des karolingischen Großreichs (714-887) », Revue de I'IFHA [En ligne], Date de recension, mis en ligne le 15 décembre 2013, consulté le 22 septembre 2020. URL http://journals.openedition.org/ifha/7703 ; DOI : https://doi.org/10.4000/ifha.7703

Ce document a été généré automatiquement le 22 septembre 2020

(CIFHA 


\section{Rudolf Schieffer, Die Zeit des} karolingischen Großreichs (714-887)

Stuttgart : Klett-Cotta (Gebhardt, Handbuch der deutschen Geschichte, 10e édition, vol. 2), 2005, 187 p., $30 €$

Philippe Depreux 
Ce qu'en Allemagne on appelle tout simplement «le Gebhardt " compte parmi les collections incontournables de l'historiographie allemande: il s'agit de volumes synthétiques présentant une encyclopédie de l'histoire allemande dont l'origine remonte à la fin du XIXe siècle. Régulièrement revus et actualisés, les volumes de cette collection offrent donc un moyen aisé d'accéder aux grandes lignes de l'histoire européenne (l'importance de la dimension européenne est soulignée p. 16), centrée sur les espaces de langue allemande. Le volume sur les temps carolingiens est donc plus particulièrement consacré à la partie orientale du monde franc. Bien que la période annoncée couvre presque tout le VIIIe et le IXe siècle, le devenir de la Francie orientale après la mort de Louis le Pieux fait figure de parent pauvre : elle n'est traitée qu'en à peine une trentaine de pages placées sous le signe du déclin (Zerfall) de l'empire (p. 136-162). C'est donc plutôt pour le VIIIe siècle que ce livre rendra de nombreux services, notamment en raison de l'approche régionale de la première partie, consacrée à l'extension franque vers l'Est, du principat de Charles Martel au couronnement impérial de Charlemagne (p. 18-68): l'histoire de la Frise, de la Franconie et de la Thuringe, de l'Alémanie, de la Bavière, de la Saxe et celle des confins septentrionaux et orientaux est présentée de manière synthétique et néanmoins précise. La seconde partie est consacrée à un tableau socio-économique et institutionnel de l'empire carolingien vers la fin du règne de Charlemagne et sous Louis le Pieux (69-136) : le nombre de page qu'occupe cette analyse où le récit politique joue également un rôle non négligeable explicite l'importance que revêt ce moment au regard de l'histoire de l'Empire. Particulièrement précieuse est la courte introduction sur la production documentaire des temps carolingiens (p. 1-18). Six arbres généalogiques synthétisent l'histoire de onze générations de maires du palais et souverains, tant à l'Est qu'à l'Ouest.

\section{INDEX}

Index chronologique : Mittelalter

Thèmes : Politische Geschichte

\section{AUTEUR}

PHILIPPE DEPREUX

Université de Limoges 